Arab Univ. J. Agric. Sci., Ain Shams Univ., Cairo, 14(1), 475-490, 2006

\title{
MITE FAUNA ASSOCIATED WITH SOME DOMESTIC AND WILD AGRICULTURAL ANIMALS AND THEIR HABITAT IN EGYPT
}

[32]

\author{
Mahgoob $^{1}$, A.E.A.; M. E. Tharwat ${ }^{1}$; Samia. O. Kilany ${ }^{1}$ and T.S. Hafez ${ }^{1}$
}

\begin{abstract}
Random samples were collected from Giza Qualubyia and Minufyia Governorates during summer, autumn and winter 2001. The collected samples were litter, poultry food and feather from chickens, ducks, pekeeny ducks, geese, rabbits (as a domestic animals) and quails, rozella birds, zebra birds and kockteel birds (as a wild animals which were in captivity). Mites belonging to twenty-seven families of four suborders; viz., Gamasida, Actinedida, Acaridida and Oribatida plus the hypopal stage of family Acaridae, were collected. Out of 27 families, 24, 14 and 11 were found in Qaliobia, Giza and Minufyia Governorates, respectively. However, number of mites, percentage of occurrence and dominance differentiated families in and between localities. Number of mites during autumn season was the highest representing 21 families followed by summer then winter. Hypopal stage represented about $20 \%$ of mite population in autumn season while no hypopal stage in summer but nil in winter. Litter harbored mites of all 27 families and hypopal stage which was not found in feather and food. The percentage of mites and hypopal stage was $89.39 \%$ in litter, followed by feather $(9.51 \%)$ then food $(1.1 \%)$. Only 6 and 5 families were found in food and feather respectively. Feather of Pekeeny ducks harbored $49.5 \%$ of mites while chicken's feather harbored $42.6 \%$. The percentage of mites in leftover food was $89 \%$ while it was $11 \%$ in food before feeding. The most common mite families in this study were Acaridae, Glycyphagidae Pyroglyphidae, Cheyletidae, Ascidae and Dermanyssidae. Declaration of the role of the animals under investigation and their habitat as a source of stored product mites also the dominance of occurrence of the recorded mite families were discussed in details.
\end{abstract}

Keywords: Litter, Chicken, Ducks, Rabbits, Wild birds, Actinedida, Acaridida,

\section{INTRODUCTION}

Mites comprise a large and economic group of Arthropoda. They are found in almost every habitat available to animal life. Several species of feather mites of the families Analgidae, Proctophyllodidae and Psoroptoididae were collected

1- Department of Plant Protection, Faculty of Agriculture, Ain Shams University, Shoubra El-Kheima, Cairo, Egypt

(Received November 26, 2005)

(Accepted December 7, 2005) 
from birds (Sohn and Noh 1994; Mironov and Kopij 1996 \& 1997 and Young-ShihMin et al 1999). Acarus siro, occurs widely in feed of cows and pigs, reducing the palatability of feed for cows and the growth rate of pigs. Tyrophagus longior extracted from bird nests, while Aleuroglyphus ovatus was found in poultry feed (Chmielewski, 1984 and Zaldivar et al 1988). In Finland a survey revealed that more mites were found in cow houses than in hay stores and Acarus siro was the most abundant species in cow houses (Leskinen et al 1987).

In Egypt, Abo-Taka (1996) found 14 mite species belonging to 11 families (Acaridae, Glycyphagidae, Analgidae, Pyroglyphidae, Dermanyssidae, Macronyssidae, Laelapidae, Cheyletidae, Tarsonemidae, Trombiculidae and Cheyletiellidae) inhabiting houses of chicken, ducks and pigeon. Astigmatid mites were in the highest population while mesostigmatid mites were the lowest

Mites significantly affect the agriculture, food, health and physical comfort of all members of our society. Many of these cause problems to poultry and farm animals, either by feeding on their blood, tissue fluids and burrowing in the skin, or by transmitting serious diseases. Consequently, meat, milk and egg production is affected. The red mite, Dermanyssus gallinae is an example of poultry parasite that also injurious to man. It was recorded on domestic fowl, pigeons, sparrows and other birds (Abo-Taka \& Allam, 1997). In recent years there has been an increasing awareness of dermatitis in humans and domestic animals. People who work in poultry farms or rearing color birds in captivity as well as those works with stored food products are suffering from irritating itch caused by mites.

Mites of stored food include species of direct effect, e.g., acarid mites, as well as predacious ones e.g., gamasid and actinedid mites. The presence of mites makes grains and their products unacceptable and unattractive to humans and livestock. Thus in a broad sense Acarina are polluters of human and animal food. There in the stored grain ecosystem may be one or more of the following: (i) energy transformer, (ii) grainvore, (iii) herbivore, (iv) predator or parasite and (v) scavenger. (Sinha, 1979).

The suborder Astigmata contains the most abundant and diverse group of mites occurring in stored product habitats. Although much is known concerning the biology and control of important pest species (Hughes, 1976), very little has been published on the evolutionary origins of stored product inhabiting Astigmata. The natural distribution of stored product pests could be one of the following categories. (i) mites associated with fruit or meat, that are not widely distributed, (ii) mites associated with field resources, and (iii) mites associated with nests of animals and birds. (Barry, 1979). Moreover, accumulated knowledge of the acari fauna associated with domestic and wild animals (mainly birds) is extremely poor as compared with other habitats. So the objectives of the present work are:

(1) Estimate the mite fauna associated with feathers, litter and poultry food before feeding (stored food) and leftover food of some domestic and wild agricultural animals in Giza, Qualubyia and Minufyia Governorates during summer, autumn and winter.

(2) Declare the role of the animals under investigation and their habitats as a 
source of mite pests to the stored products.

\section{MATERIAL AND METHODS}

Random samples were collected from Giza Qualubyia and Minufyia Governorates during summer, autumn and winter 2001. The collected samples were litter, poultry food and feather from chickens, ducks, pekeeny ducks, geese, rabbits (as a domestic animals) and quails, rozella birds, zebra birds and kockteel birds (as a wild animals which were in captivity).

\section{Samples}

a:- Litters: were taken from under hosts and were containing animal feces, feed powder, feather fragments and dust, each samples was about $500 \mathrm{~g}$.

b:- Feather: were removed from alive animals, each sample was about $25 \mathrm{~g}$.

c:- Poultry food: about 500 g. from the chicken food before feeding (stored food) and after feeding (leftover food) were taken.

All samples were collected from poultry farms, farmer's houses, and public houses then placed in plastic bags, tightly closed with rubber bands and transferred as soon as possible to the laboratory of the Plant Protection Department, Faculty of Agriculture Ain Shams University for mite extraction.

\section{Extraction of mites}

About 100 g. samples of litter animals, and chicken food singly mixed, and 25-gm feather samples were taken. The samples were spread over muslin in the Tullgren (modified Berlese) funnels in 2 $\mathrm{cm}$. deep layers. The extracted mites were received in Petri dishes filled with about $25 \mathrm{~cm}$. of tap water. Twenty-four hours later, extraction contents of the Petri dishes were examined using dissecting microscope. Adults and immature stages of mites were mounted on microscopic glass slides in modified Berlese fluid (Schuster and Pritchard, 1963) for identification and counting using light microscope. Number of mites per sample was attributed to one kilogram.

\section{Identification of mites}

Identification was carried out to the level of the family using keys erected by Hughes (1976); Krantz (1978) and Zaher (1986).

\section{Dominance of occurrence}

Dominance terminology used by $\mathbf{C u}-$ sack et al (1975) was adopted. According to the total population of each family, the order of dominance was divided into three categories: dominant $(+++)$, influent $(++)$ and recedent $(+)$

\section{RESULTS}

\section{Mite families inhabiting feather, lit- ter and chicken food}

Litters contained the highest average number of mites followed by those associated with feather and those inhabiting both stored and left over poultry food (Table, 1). However five mite families 
were extracted from feather of domestic idae, and wild birds. These families were Acar-

Ascidae,

Cheyletidae, 
Table 1. Average number, percentage of occurrence and dominance of mites associated with samples $(1 \mathrm{Kg}$. each) of different domestic and wild agricultural animal materials.

\begin{tabular}{|c|c|c|c|c|c|c|c|c|c|}
\hline \multirow[b]{2}{*}{ Family name } & \multicolumn{3}{|c|}{ Feather } & \multicolumn{3}{|c|}{ Litter } & \multicolumn{3}{|c|}{ Food } \\
\hline & $\begin{array}{c}\text { Average/ } \\
\mathrm{Kg}\end{array}$ & $\begin{array}{c}\% \text { of } \\
\text { occur- } \\
\text { ance }\end{array}$ & $\begin{array}{l}\text { Domi- } \\
\text { nance }\end{array}$ & $\begin{array}{c}\text { Average/ } \\
\mathrm{Kg}\end{array}$ & $\begin{array}{c}\% \text { of } \\
\text { occur- } \\
\text { ance }\end{array}$ & $\begin{array}{l}\text { Domi- } \\
\text { nance }\end{array}$ & $\begin{array}{c}\text { Average/ } \\
\mathrm{Kg}\end{array}$ & $\begin{array}{c}\% \text { of } \\
\text { occur- } \\
\text { ance }\end{array}$ & $\begin{array}{l}\text { Domi- } \\
\text { nance }\end{array}$ \\
\hline Acaridae & 18 & 0.47 & + & 3365.9 & 9.29 & +++ & 327 & 73.68 & +++ \\
\hline Acarophenacidae & & & & 544 & 1.5 & + & & & \\
\hline Ameroseiidae & & & & 15 & 0.04 & + & & & \\
\hline Ascidae & 183 & 4.75 & + & 1647 & 4.55 & +++ & 20 & 4.51 & + \\
\hline Bdellidae & & & & 1041.4 & 2.88 & ++ & & & \\
\hline Cheyletidae & 256.5 & 6.65 & + & 12680 & 35.01 & +++ & 59.8 & 13.47 & ++ \\
\hline Chortoglyphidae & & & & 1183.8 & 3.27 & ++ & & & \\
\hline Cunaxidae & & & & 3 & 0.01 & + & & & \\
\hline Dermanyssidae & & & & 4071.5 & 11.24 & +++ & & & \\
\hline Glycyphagidae & 1845 & 47.86 & +++ & 3418.5 & 9.44 & +++ & & & \\
\hline Hypopal stage & & & & 4953.5 & 13.68 & +++ & & & \\
\hline Laelapidae & & & & 2 & 0.01 & + & & & \\
\hline Macrochelidae & & & & 95 & 0.26 & + & & & \\
\hline Oribatulidae & & & & 44 & 0.12 & + & 16 & 3.61 & + \\
\hline Parasitidae & & & & 261 & 0.72 & + & & & \\
\hline Phytoseiidae & & & & 650.2 & 1.8 & ++ & & & \\
\hline Pyemotidae & & & & 9 & 0.02 & + & & & \\
\hline Pygmephoridae & & & & 127 & 0.35 & + & & & \\
\hline Pyroglyphidae & 1552.3 & 40.27 & +++ & 728 & 2.01 & ++ & 14 & 3.15 & + \\
\hline Raphignathidae & & & & 16.9 & 0.05 & + & & & \\
\hline Rhagidiidae & & & & 2 & 0.01 & + & & & \\
\hline Rhodacaridae & & & & 101.5 & 0.28 & + & & & \\
\hline Sarcoptidae & & & & 92 & 0.25 & + & & & \\
\hline Stigmaeidae & & & & 189 & 0.52 & + & & & \\
\hline Tarsonemidae & & & & 478 & 1.32 & + & & & \\
\hline Tetranychidae & & & & 33 & 0.09 & + & & & \\
\hline Tydeidae & & & & 453 & 1.25 & + & & & \\
\hline Uropodidae & & & & 9 & 0.03 & + & 7 & 1.58 & + \\
\hline Total & 3854.8 & & & 36214.2 & & & 443.8 & & \\
\hline$\%$ & 9.51 & & & 89.39 & & & 1.1 & & \\
\hline No. of Families & 5 & & & 27 & & & 6 & & \\
\hline
\end{tabular}


Glycy phagidae, and Pyroglyphidae. Glycyphagidae and Pyroglyphidae proved to be "dominant" represent $47.86 \%$ and $40.27 \%$ of the total collected mites, respectively. The other three families were "resident" where they form from $0.47 \%$ to $6.65 \%$ of the total collected mites.

Food samples sheltered six mite families i.e., Acaridae, Ascidae, Cheyletidae, Oribatulidae, Pyroglyphidae and Uropodidae. Acarid mites were considered to be "dominant" since they represented $73.68 \%$ of the total collected mites. The cheyletid mites were "influent", represented by $13.47 \%$ of the total collected mites, while other families were "resident" where their population percentage ranged between $1.58 \%$ (Uropodidae) to $4.51 \%$ (Ascidae).

All mite families (27 families plus the acarid hypopal stage) were occurred in litter of the chosen domestic and wild agricultural animals. The "dominant" families were Acaridae, Ascidae, Cheyletidae, Dermanyssidae, Glycyphagidae, and the hypopal stage, representing $9.22 \%, 4.55 \%, 35.01 \%, 11.24 \%, 9.44$ $\%$ and $13.68 \%$ of the total collected mites, respectively. Families Bdellidae, Chortoglyphidae, Phytoseiidae, and Pyroglyphidae were considered to be "influent" where they represented by $2.88 \%$, $3.27 \%, 1.8 \%$ and $2.01 \%$ of the total collected mites, respectively. The other mite families were "resident" since their population percentage ranged between $0.01 \%$ (Cunaxidae, Laelapidae and Rhagidiidae) to $1.5 \%$ (Acarophenacidae).

Twenty families were found in litter only. One family (Glycyphagidae) was collected from both litter and feather. Two families (Oribatulidae and Uropodidae) were collected from both litter and food. Family Acaridae, Ascidae,
Cheyletidae and Pyroglyphidae were found inhabiting feather, litter and food.

\section{Mite families associated with sam- ples of different domestic and wild agricultural animal materials col- lected from Giza, Minufyia and Qualubyia Governorates}

The total average number of mites collected from Giza, Minufyia and Qualubyia Governorates were 6903.7, 11380.6 and 22228.5 mites, respectively. Data given in Table (2) indicates that samples collected from Giza Governorate sheltered 14 mite families plus the acarid hypopal stage. Of these 5 families (Acaridae, Acarophenacidae, Ascidae, Bidellidae and Cheyletidae plus the hypopal stage of the Acaridae were "dominant" where their population percentage ranged between $23.07 \%$ (Acaridae) and $7.88 \%$ (Acarophenacidae). The other nine families were "resident" where their population percentage ranged between $0.13 \%$ (Tarsonemidae) and $2.01 \%$ (Phytoseiidae).

Samples collected from Qualubyia Governorate sheltered 24 families plus the acarid hypopal stage. Six families were "dominant", with average population percentage ranging between $38.70 \%$ (Cheyletidae) and $5.33 \%$ (Chortoglyphidae). Two families were "influent" (Phytoseiidae and Tarsonemidae) represented by $2.3 \%$, and $2.1 \%$, respectively. The other 17 families were "resident", and their population percentage ranged between $0.01 \%$ (Bdellidae, Laelapidae, and Rhagidiidae) and $1.34 \%$ (Family Ascidae).

Eleven Families were found in samples collected from Minufyia Governorate. Of these three families were 
Table 2. Average number, percentage of occurrence and dominance of mites associated with litter, food samples $(1 \mathrm{Kg}$. each) of different domestic and wild agricultural animals collected from Giza, Minufyia and Qualubyia governorates.

\begin{tabular}{|c|c|c|c|c|c|c|c|c|c|}
\hline \multirow[b]{2}{*}{ Family name } & \multicolumn{3}{|c|}{ Giza } & \multicolumn{3}{|c|}{ Minufyia } & \multicolumn{3}{|c|}{ Qualubyia } \\
\hline & $\begin{array}{c}\text { Average/ } \\
\mathrm{Kg}\end{array}$ & $\begin{array}{c}\% \text { of } \\
\text { occur- } \\
\text { ance }\end{array}$ & $\begin{array}{l}\text { Domi- } \\
\text { nance }\end{array}$ & $\begin{array}{c}\text { Average/ } \\
\mathrm{Kg}\end{array}$ & $\begin{array}{c}\% \text { of } \\
\text { occur- } \\
\text { ance }\end{array}$ & $\begin{array}{l}\text { Domi- } \\
\text { nance }\end{array}$ & $\begin{array}{c}\text { Average/ } \\
\mathrm{Kg}\end{array}$ & $\begin{array}{l}\text { of } \% \\
\text { occur- } \\
\text { ance }\end{array}$ & $\begin{array}{l}\text { Domi- } \\
\text { nance }\end{array}$ \\
\hline Acaridae & 1593 & 23.07 & +++ & 309.2 & 2.72 & + & 1808.7 & 8.14 & +++ \\
\hline Acarophenacidae & 544 & 7.88 & +++ & & & & & & \\
\hline Ameroseiidae & & & & & & & 15 & 0.07 & + \\
\hline Ascidae & 1543 & 22.35 & +++ & 10 & 0.09 & + & 297 & 1.34 & + \\
\hline Bdellidae & 988 & 14.31 & +++ & 50 & 0.44 & + & 3.4 & 0.01 & + \\
\hline Cheyletidae & 638.2 & 9.24 & +++ & 3755.5 & 33 & +++ & 8602.6 & 38.7 & +++ \\
\hline Chortoglyphidae & & & & & & & 1183.8 & 5.33 & +++ \\
\hline Cunaxidae & & & & 3 & 0.02 & + & & & \\
\hline Dermanyssidae & & & & 3897 & 34.24 & +++ & 174.5 & 0.78 & + \\
\hline Glycyphagidae & 100.5 & 1.46 & + & 2754 & 24.2 & +++ & 2409 & 10.83 & +++ \\
\hline Hypopal stage & 1062 & 15.38 & +++ & & & & 3891.5 & 17.51 & +++ \\
\hline Laelapidae & & & & & & & 2 & 0.01 & + \\
\hline Macrochelidae & 22 & 0.32 & + & & & & 73 & 0.33 & + \\
\hline Oribatulidae & & & & 17 & 0.15 & + & 43 & 0.19 & + \\
\hline Parasitidae & 101 & 1.46 & + & & & & 160 & 0.72 & + \\
\hline Phytoseiidae & 139 & 2.01 & + & & & & 511.2 & 2.3 & ++ \\
\hline Pyemotidae & & & & & & & 9 & 0.04 & + \\
\hline Pygmephoridae & 48 & 0.7 & + & & & & 79 & 0.35 & + \\
\hline Pyroglyphidae & & & & 176 & 1.55 & + & 2118.3 & 9.53 & +++ \\
\hline Raphignathidae & & & & 16.9 & 0.15 & + & & & \\
\hline Rhagidiidae & & & & & & & 2 & 0.01 & + \\
\hline Rhodacaridae & 64 & 0.93 & + & & & & 37.5 & 0.17 & + \\
\hline Sarcoptidae & 26 & 0.38 & + & & & & 66 & 0.3 & + \\
\hline Stigmaeidae & & & & & & & 189 & 0.85 & + \\
\hline Tarsonemidae & 9 & 0.13 & + & & & & 469 & 2.11 & ++ \\
\hline Tetranychidae & & & & & & & 33 & 0.15 & + \\
\hline Tydeidae & 26 & 0.38 & + & 392 & 3.44 & + & 35 & 0.16 & + \\
\hline Uropodidae & & & & & & & 16 & 0.07 & + \\
\hline Total & 6903.7 & & & 11380.6 & & & 22228.5 & & \\
\hline$\%$ & 17.04 & & & 28.1 & & & 54.86 & & \\
\hline No. of Families & 14 & & & 11 & & & 24 & & \\
\hline
\end{tabular}


"dominant" (Dermanyssidae, Cheyletidae and Glycyphagidae), represented by $34.24 \%, 33.0 \%$ and $24.2 \%$, respectively. The other eight families were considered "resident" where their population percentage ranged between $0.02 \%$ (Cunaxidae) and $3.44 \%$ (Tydeidae).

\section{A. Mites found in samples collected from three Governorates}

Acaridae, Ascidae, Bdellidae, Cheyletidae, Glycyphagidae and Tydeidae were associated with samples collected from Giza, Qualubyia and Minufyia Governorates.

\section{B. Mites found in samples collected from two Governorates}

Eight Families were found inhabiting samples collected from Giza and Qualubyia Governorates: Hypopal stage of Family Acaridae, Macrochelidae, Parasitidae, Phytoseiidae, Pygmephoridae, Rhodacaridae, Sarcoptidae and Tarsonemidae. Three families were found in Qualubyia and Minufyia Governorate (Dermanyssidae, Oribatulidae and Pyroglyphidae.

\section{Mites found in samples collected from one Governorate}

Family Acarophenacidae was found in Giza Governorate only; families Ameroseiidae, Chortoglyphidae, Laelapidae, Pyemotidae, Rhagidiidae, Stigmaeidae, Tetranychidae, and Uropodidae were found in Qualubyia Governorate only, and families Cunaxidae and Raphignathidae found in Minufyia only.

\section{Mites associated with some domestic and wild agricultural animals dur- ing summer, autumn and winter}

The average total number of mites collected during summer, autumn and winter were 9110.4, 24367.5 and 7034.9 mites, respectively (Table 3 ). During summer, 22 families were found associated with the examined materials. Six families of them (Acaridae, Ascidae, Cheyletidae, Chortoglyphidae, Pyroglyphidae and Tarsonemidae) were "dominant" and their population percentage ranged between $4.7 \%$ (Tarsonemidae), and $44.50 \%$ (Cheyletidae). The other families were "resident" where their population percentage ranged between $0.01 \%$ (Pyemotidae) and $2.10 \%$ (Stigmaeidae).

During autumn, 21 families were extracted plus the acarid hypopal stage. Four families (Acaridae, Cheyletidae, Dermanyssidae, Glycyphagidae) and hypopal stage of Acaridae were "dominant", and their population percentage ranged between $10.17 \%$ (Acaridae) and $20.67 \%$ (Cheyletidae). Four families (Ascidae, Phytoseiidae, Pyroglyphidae and Bdellidae) were "influent" where they were represented by $2.65 \%, 2.67 \%, 2.82 \%$ and $4.26 \%$, respectively. The rest were considered to be "resident" where their population percentage ranged between $0.01 \%$ (Cunaxidae) and 2.22\% (Acarophenacidae).

During winter, 8 families and the acarid hypopal stage were recorded. Two families were "dominant", Cheyletidae (55.51\%) and Glycyphagidae (25.88\%). Ascidae was considered to be "influent" $(9.51 \%)$. The rest were "resident" and their population percentage ranged between $0.09 \%$ (Oribatulidae) and 1\% (acarid hypopal stage). 
Table 3. Average number, percentage of occurrence and dominance of mites associated with samples (1 Kg each) of different domestic and wild agricultural animal materials during summer, autumn and winter.

\begin{tabular}{|c|c|c|c|c|c|c|c|c|c|}
\hline \multirow[b]{2}{*}{ Family name } & \multicolumn{3}{|c|}{ Summer } & \multicolumn{3}{|c|}{ Autumn } & \multicolumn{3}{|c|}{ Winter } \\
\hline & $\begin{array}{c}\text { Average/ } \\
\mathrm{Kg}\end{array}$ & $\begin{array}{c}\% \text { of } \\
\text { occur- } \\
\text { ance }\end{array}$ & $\begin{array}{l}\text { Domi- } \\
\text { nance }\end{array}$ & $\begin{array}{c}\text { Average/ } \\
\mathrm{Kg}\end{array}$ & $\begin{array}{c}\% \text { of } \\
\text { occur- } \\
\text { ance }\end{array}$ & $\begin{array}{l}\text { Domi- } \\
\text { nance }\end{array}$ & $\begin{array}{c}\text { Average/ } \\
\mathrm{Kg}\end{array}$ & $\begin{array}{c}\% \text { of } \\
\text { occur- } \\
\text { ance }\end{array}$ & $\begin{array}{l}\text { Domi- } \\
\text { nance }\end{array}$ \\
\hline Acaridae & 748 & 8.21 & +++ & 2477.9 & 10.17 & +++ & 485 & 6.89 & ++ \\
\hline Acarophenacid & 3 & 0.03 & + & 541 & 2.22 & + & & & \\
\hline Ameroseiidae & 15 & 0.2 & + & & & & & & \\
\hline Ascidae & 536 & 5.9 & +++ & 645 & 2.65 & ++ & 669 & 9.51 & ++ \\
\hline Bdellidae & 3.4 & 0.04 & + & 1038 & 4.26 & ++ & & & \\
\hline Cheyletidae & 4054.2 & 44.5 & +++ & 5036.7 & 20.67 & +++ & 3905.4 & 55.51 & +++ \\
\hline Chortoglyphidae & 1175 & 12.9 & +++ & 8.8 & 0.04 & + & & & \\
\hline Cunaxidae & & & & 3 & 0.01 & + & & & \\
\hline Dermanyssidae & 174.5 & 1.9 & + & 3897 & 15.99 & +++ & & & \\
\hline Glycyphagidae & 42 & 0.5 & + & 3401 & 13.96 & +++ & 1820.5 & 25.88 & +++ \\
\hline Hypopal stage & & & & 4883.5 & 20.04 & +++ & 70 & 1 & + \\
\hline Laelapidae & 2 & 0.02 & + & & & & & & \\
\hline Macrochelidae & 36 & 0.4 & + & 59 & 0.24 & + & & & \\
\hline Oribatulidae & 28 & 0.3 & + & 26 & 0.11 & + & 6 & 0.09 & + \\
\hline Parasitidae & & & & 214 & 0.88 & + & 47 & 0.67 & + \\
\hline Phytoseiidae & & & & 650.2 & 2.67 & ++ & & & \\
\hline Pyemotidae & 9 & 0.01 & + & & & & & & \\
\hline Pygmephoridae & 7 & 0.08 & + & 96 & 0.39 & + & 24 & 0.34 & + \\
\hline Pyroglyphidae & 1607.3 & 17.6 & +++ & 687 & 2.82 & ++ & & & \\
\hline Raphignathidae & & & & 16.9 & 0.07 & + & & & \\
\hline Rhagidiidae & 2 & 0.02 & + & & & & & & \\
\hline Rhodacaridae & & & & 101.5 & 0.42 & + & & & \\
\hline Sarcoptidae & 2 & 0.02 & + & 90 & 0.37 & + & & & \\
\hline Stigmaeidae & 189 & 2.1 & + & & & & & & \\
\hline Tarsonemidae & 426 & 4.7 & +++ & 44 & 0.18 & + & 8 & 0.11 & + \\
\hline Tetranychidae & 9 & 0.1 & + & 24 & 0.1 & + & & & \\
\hline Tydeidae & 26 & 0.3 & + & 427 & 1.75 & + & & & \\
\hline Uropodidae & 16 & 0.2 & + & & & & & & \\
\hline Total & 9110.4 & & & 24367.5 & & & 7034.9 & & \\
\hline$\%$ & 22.49 & & & 60.01 & & & 17.36 & & \\
\hline No. of Families & 22 & & & 21 & & & 8 & & \\
\hline
\end{tabular}


A-: Families occurred during the three seasons: Acaridae, Ascidae, Cheyletidae, Glycyphagidae, Oribatulidae, Pygmephoridae, and Tarsonemidae were recorded during summer, autumn and winter.

\section{B-: Families occurred during two} seasons: Acarophenacidae, Bdellidae, Chortoglyphidae, Dermanyssidae, Macrochelidae, Pyroglyphidae, [Sarcoptidae, Tetranychidae and Tydeidae were recorded during summer and autumn. The hypopal stage and family Parasitidae were recorded during autumn and winter.

\section{C-: Families occurred during one} season: The following families were recorded during summer months only: Ameroseiidae, Laelapidae, Pyemotidae, Rhagidiidae, Stigmaeidae, and Uropodidae. While Cunaxidae, Phytoseiidae,
Raphignathidae and Rhodacaridae were found during autumn only.

\section{4- Mites associated with feather of dif- ferent domestic and wild agricul- tural birds}

Data given in Table (4) show that five mite families were recorded associated with feather of the chosen domestic and wild agricultural birds. Three of them Cheyletidae, Acaridae and Glycyphagidae were found inhabiting feather of ducks pekeeny. Two families, Ascidae and Pyroglyphidae, were found inhabiting feather of chicken. Feather of ducks, geese, quails and zibra birds sheltered one family each. The highest average number of mites/Kg. (1544.3 pyroglyphid mites) was found inhabiting chickens feather, while the lowest number $(8.0$ pyroglyphid mites) extracted from ducks feather.

Table 4. Average number of mites associated with feather samples (1Kg each) of different domestic and wild agricultural birds

\begin{tabular}{|c|c|c|c|c|c|c|c|c|}
\hline \multirow[b]{2}{*}{ Family name } & \multicolumn{6}{|c|}{ Birds } & \multirow[b]{2}{*}{ Total } & \multirow{2}{*}{$\begin{array}{c}\text { Average/ } \\
\mathrm{Kg}\end{array}$} \\
\hline & Chickens & Ducks & $\begin{array}{c}\text { Pekeeny } \\
\text { Ducks }\end{array}$ & Geese & $\begin{array}{l}\text { Quail } \\
\text { birds }\end{array}$ & $\begin{array}{c}\text { Zebra } \\
\text { birds }\end{array}$ & & \\
\hline Ascidae & 100 & & & & 83 & & 183 & 91.5 \\
\hline Cheyletidae & & & 45 & 80.5 & & 131 & 256.5 & 85.5 \\
\hline Acaridae & & & 18 & & & & 18 & 18 \\
\hline Glycyphagidae & & & 1845 & & & & 1845 & 1845 \\
\hline Pyroglyphidae & 1544.3 & 8 & & & & & 1552 & 776.35 \\
\hline Total & 1644.3 & 8 & 1908 & 80.5 & 83 & 131 & 3854.8 & \\
\hline$\%$ & 42.6 & 0.2 & 49.5 & 2.1 & 2.2 & 3.4 & & \\
\hline No. of Families & 2 & 1 & 3 & 1 & 1 & 1 & & \\
\hline
\end{tabular}


Family Cheyletidae was found to be associated with three feather types namely pekeeny ducks, geese and zebra birds. On the other hand, members of family Glycyphagidae though found in one type of feather, pekeeny ducks, yet they were represented by as high as 1845 mites $/ \mathrm{Kg}$. Family Acaridae was found inhabiting one type of feather, pekeeny ducks, (18 mites/Kg). The lowest average number of mites (8 pyroglyphids) was found associated with ducks feather. While the highest average number was recorded on pekeeny ducks (1845 glycyphagids).

\section{5- Mites associated with litter of differ- ent domestic and wild agricultural animals}

Data given in Table (5) show that litter of 9 domestic and wild agricultural animals was tested for mite families. The highest number of families (15) was recorded inhabiting litter of pigeons and rabbits. On the other hand, rozela litter sheltered only one family (Ascidae). The highest and lowest number of mites/Kg were recorded inhabiting litter of rabbits (9822.4 mites) and rozela (275 mites), respectively. Family Cheyletidae was found inhabiting all types of litter except rozela litter. The average number of mites/ Kg was 1585 individuals ranging between 70 (rabbits litter) to 8216.6 (chickens litter).

Family Acaridae was recorded in 7 types of litter with an average of 480.8 mites/Kg Families Ascidae, Glycyphagidae, Tarsonemidae and Tydeidae, were found inhabiting 6 types of litter with an average of $274.5,569.8,79.7$ and 75.5 mites/Kg, respectively. Bdellidae, Dermanyssidae, Oribatulidae, Pygmephoridae and Pyroglyphidae, were collected from 3 types of litter with an average of 347.1, 1357.2, 14.7, 42.3, and 242.7 mites/Kg, respectively. Acarophenacidae, Chortoglyphidae, hypopal stage of Acaridae, Macrochelidae, Phytoseiidae, Sarcoptidae, Stigmaeidae, and Tetranychidae, were recorded in two types of litter with an average of mites/ Kg ranging between 16.5 (Tetranychidae) to 2476.8 (hypopal stage). The rest (9 families) were found in only one type of litter, with an average number of mites / $\mathrm{Kg}$. ranging between 2 (Laelapidae and Rhagidiidae) to 261 (Parasitidae).

\section{6- Mite families inhabiting chickens food before feeding and leftover food}

Data given in Table (6) show that leftover food sheltered 6 families. Family Acaridae recorded the highest number of mites (311 mite/kg) followed by family Cheyletidae (27 mites $/ \mathrm{kg}$ ) while family Oribatulidae recorded the lowest one (7 mites $/ \mathrm{kg}$ ). Samples of food before feeding (stored food), contained only two families: Acaridae and Cheyletidae. The number of family Acaridae increased from 16 mites $/ \mathrm{kg}$ in the food (before feeding) to $311 \mathrm{mites} / \mathrm{kg}$ in the leftover food, however there was an opposite trend with family Cheyletidae. Generally leftover food contained $89 \%$ of total mites while food before feeding contained $11 \%$. 
Table 5. Average number of mites associated with litter samples (1Kg. each) of different domestic and wild agricultural animals.

\begin{tabular}{|c|c|c|c|c|c|c|c|c|c|c|c|}
\hline \multirow[b]{2}{*}{ Family name } & \multicolumn{10}{|c|}{ Animals } & \multirow[b]{2}{*}{$\begin{array}{c}\text { Average } \\
/ \mathrm{Kg}\end{array}$} \\
\hline & Chikens & Pegions & Ducks & $\begin{array}{l}\text { Pekee- } \\
\text { ny } \\
\text { ducks }\end{array}$ & Geese & $\begin{array}{c}\text { Rozella } \\
\text { birds }\end{array}$ & $\begin{array}{c}\text { Zebra } \\
\text { birds }\end{array}$ & $\begin{array}{l}\text { Kockte- } \\
\text { el birds }\end{array}$ & Rabbits & total & \\
\hline Acaridae & 522 & 120 & 140.7 & 165.5 & 31 & & & 63 & 2323.7 & 3365.9 & 480.8 \\
\hline Acarophenacidae & & & & & 3 & & 541 & & & 544 & 272 \\
\hline Ameroseiidae & & & & & 15 & & & & & 15 & 15 \\
\hline Ascidae & & & 10 & & 32 & 257 & 301 & 773.5 & 273.5 & 1647 & 274.5 \\
\hline Bdellidae & & 3.4 & & 50 & & & 988 & & & 1041.4 & 347.1 \\
\hline Cheyletidae & 8216.6 & 154.7 & 182.9 & 3472 & 125.3 & & 218.5 & 240 & 70 & 12680 & 1585 \\
\hline Chortoglyphidae & 25.8 & 1158 & & & & & & & & 1183.8 & 591.9 \\
\hline Cunaxidae & & & 3 & & & & & & & 3 & 3 \\
\hline Dermanyssidae & 162 & 12.5 & 3897 & & & & & & & 4071.5 & 1357.2 \\
\hline Glycyphagidae & 216 & 27 & 1840 & & 854 & & & 100.5 & 381 & 33418.5 & 569.8 \\
\hline Hypopal stage & 17 & & & & & & & & 4936.5 & 4953.5 & 2476.8 \\
\hline Laelapidae & & 2 & & & & & & & & 2 & 2 \\
\hline Macrochelidae & & 36 & & & & & & & 59 & 95 & 47.5 \\
\hline Oribatulidae & 25 & 2 & 17 & & & & & & & 44 & 14.7 \\
\hline Parasitidae & & & & & & & & & 261 & 261 & 261 \\
\hline Phytoseiidae & & & 25 & & & & & & 625.2 & 650.2 & 325.1 \\
\hline Pyemotidae & 9 & & & & & & & & & 9 & 9 \\
\hline Pygmephoridae & & 7 & 24 & & & & & & 96 & 127 & 42.3 \\
\hline Pyroglyphidae & 49 & & 168 & & & & & & 511 & 728 & 242.7 \\
\hline Raphignathidae & & & 16.9 & & & & & & & 16.9 & 16.9 \\
\hline Rhagidiidae & & 2 & & & & & & & & 2 & 2 \\
\hline Rhodacaridae & & & & & & & & & 101.5 & 101.5 & 101.5 \\
\hline Sarcoptidae & & 2 & & & & & & & 90 & 92 & 46 \\
\hline Stigmaeidae & & 104 & & & 85 & & & & & 189 & 94.5 \\
\hline Tarsonemidae & 21 & 386 & 2 & & 16 & & 9 & & 44 & 478 & 79.7 \\
\hline Tetranychidae & 9 & & & & & & & & 24 & 33 & 16.5 \\
\hline Tydeidae & 9 & 18 & 292 & 100 & 8 & & & & 26 & 453 & 75.5 \\
\hline Uropodidae & 9 & & & & & & & & & 9 & 9 \\
\hline Total & 9290.4 & 2034.6 & 6618.5 & 3787.5 & 1169.3 & 257 & 2057.5 & 1177 & 9822.4 & 36214.2 & \\
\hline$\%$ & 25.7 & 5.6 & 18.3 & 10.5 & 3.2 & 0.7 & 5.7 & 3.3 & 27.1 & & \\
\hline No. of Families & 13 & 15 & 13 & 4 & 9 & 1 & 5 & 4 & 15 & & \\
\hline
\end{tabular}

Arab Univ. J. Agric. Sci., 14(1), 2006 
Table 6. Average number of mites associated with food before feeding (stored food) and leftover poultry food per $\mathrm{Kg}$. each.

\begin{tabular}{|lcccc|}
\hline Family name & $\begin{array}{c}\text { Leftover } \\
\text { food }\end{array}$ & $\begin{array}{c}\text { Food before } \\
\text { feeding }\end{array}$ & Total & Average/ Kg \\
\hline Ascidae & 20 & & 20 & 20 \\
Uropodidae & 7 & & 7 & 7 \\
Cheyletidae & 27 & 32.8 & 59.8 & 29.9 \\
Acaridae & 311 & 16 & 327 & 163.5 \\
Pyroglyphidae & 14 & & 14 & 14 \\
Oribatulidae & 16 & & 16 & 16 \\
\hline Total & 395 & 48.8 & 443.8 & \\
\hline$\%$ & 89 & 11 & & \\
\hline No. of families & 6 & 2 & & \\
\hline
\end{tabular}

\section{DISCUSSION}

The obtained data in Tables (1-3) indicated that there were 27 mite families plus hypopal stage of acarid mites collected from feather, litters and animal food during autumn, summer and winter seasons at three Governorates. The most abundant mite families were Acaridae, Cheyletidae, Dermanyssidae, Glycyphagidae in addition to acarid hypopal stage. Also the above-mentioned families recorded high number of mites within the tested materials especially litter. The present results supported by the finding of Abo-Taka (1996) who found that 14 mite species belonging to 11 families collected from chickens, ducks and pigeons farms in Egypt. Also Corpuz-Raros et al (1988) and Rueda \& Axtel (1997) extracted 20 and 9 mite families collected from poultry houses in Philippines and USA respectively. Moreover they men- tioned that the most common mites were acarids, cheyletids, glycypagids and dermanyssids. Regarding to the normal distribution of mites through the different seasons, it could be observed that the highest average number of mites recorded during autumn and summer. Similar results were obtained by Leskinen et al (1987); El-Kammah et al (1990) and Abo-Taka (1996).

Data in Tables (3-6) revealed that the highest average number of mites were recorded in the litter's of rabbits (9822.4), chickens, (9290.4) and ducks (6618.5). also the most abundant families were Acridae, Cheyletidae, Dermanyssidae, Chortoglyphidae, Glycyphagidae and the hypopal stage with an average number of mites ranged between 480.8 to 2476.8 mites $/ \mathrm{kg}$ moreover the above-mentioned mite families recorded the highest number of mites in the litters of chickens, pigeons, ducks and rabbits than the other 
litters (Table 5). Here again similar observation found by El-Kammah et al (1990) and Abo-Taka (1996).

The litters of wild birds which were in captivity contained a significant mite numbers of parasitic and predator groups of mite family i.e Acarophenacidae, Ascidae, Bdellidae and Cheyletidae. Meanwhile the acarid and Glycyphagid mites which consider as a stored product pests recorded the lowest numbers. Moreover the dermanyssid mites were not recorded too. (Table 5), this could be due to the presence of parasitic and predator mites or conteniously taking care by those birds. However the wild agriculture birds or their nests such as house sparrow contain more mite species and families. In study of mite fauna associated with Passer domesticus niloticus and Streptopelia senegalensis aegyptiaca in Sharkia and Qalyobia Governorates conducted by Morsy et al (1999). There were 31 species belonging to 23 genera, 17 families of mites associated with the previous hosts, in the same time the most common mite families were Dermanyssidae, Cheyletidae, Glycyphagidae, Acaridae and some other feather mites.

Regarding to the feather mites in the present work it is worthy to mention that there is no specific feather mites were recorded on neither domestic nor wild birds. On the other hand, the most common mites were stored product mites associated with domestic birds (Table 4).

Concerning the poultry food before and after feeding (Table 6), more mite families were present in the leftover food than the stored food (before feeding), furthermore the acarid mites significantly increased in number in the leftover food. The probability is more mite families with the respect of acarid mites trans- ferred from the chickens litter to their food, so the mite of stored product could reach the store rooms attached with the poultry farms or in farmer's houses. About 50 species of mites occur in grain storage premises containing grains, flour, oilseed and animal feeding material, some of them also occur in bird or rodent nests and agricultural field. (Sinha, 1979). However, the largest group of stored product inhabiting genera is derived from nests of mammals especially rodents, followed by bird nests. The derivation of stored product mites from rodent nests is twofold. First, the nest materials itself provides a substrate for the specific fungi required as food by the mites, and second, a large number of rodents store various plant parts as food in chambers within their burrow system. (Barry, 1979). The previous observation strongly supports the present work. However, here again the highest number of stored product mites (Acaridae, Glycyphagidae, Pyroglyphidae, and the hypopal stage of Acaridae) was found in the litter of rabbits, chickens, pigeons and ducks, which have similar conditions as in the nests of rodents or birds. So the litters of domestic animals could be another major source of the stored product mites.

\section{REFERENCES}

Abo-Taka, S.M. (1996). Mites inhabiting poultry farms in Egypt. In: Rodger, M.; H.J. David; N.R. Glen and W.C. Welbourn. Acarology, IX Proceedings. Ohio Bological Survey Columbus, Ohio, pp. 97-99.

Abo-Taka, S.M. and S.A. Allam (1997). Incidence, distribution, and ecology of ectoparasitic Acari infesting poultry farms in Menoufia Governorate, Egypt. Menofiya J. Agric. Res. 22 (2): 389-403. 
Barry, M.O. (1979). Evalutionary origins of astimatid mites inhabiting stored products. In: Rodtiguez, I.G. (Ed.) Recent Advances in Acarology l: 273-278., Academic Press Inc., New York.

Chmielewski, W. (1984). Tyrophagus longior (Gerv., 1844) (Acarina, Acaridae)- bioecology, occurrence and harmfulness. Prace Naukowe Instytutu Ochrony Roslin. 26 (1): 69-85.

Corpuz-Raros, L.A.; G.C. Sabio and M. Velasco-Soriano (1988). Mites associated with stored products, poultry houses and house dust in the Philippines. Philippine Entomologist. 7 (3): 311-321.

Cusak, P.D.; G.O. Evans and P.A. Brennan (1975). A survey of the mites of stored grain and grain products in the republic of Ireland. The Scientific Proceedings of the Royal Dublin Society Series B, 3 (20): 273-329.

El-Kammah, K.M.; L.I. Oyoun; M.H. Madbouly and S.M. Habeeb (1990). Colonization and life cycle study of the chicken mite Ornithonyssus bursa (Berlese 1888) (Dermanyssidae). Bulletin de la Societe Entomologique d'Egypte. 69: 277-285.

Hughes, A.M. (1976). The mites of stored food and houses. Minst. of Agric., Fish. \& Food, London, Technical Bull 9: $400 \mathrm{pp}$.

Krantz, G.W. (1978). A Manual of Acarology. 509 pp. Oregon State University Book Stores, Inc. Corvallis, Oregon.

Leskinen, L.; T. Klen and E.O. Terho (1987). Storage mites in the work environment of farmes. European Journal of Respiratory Direase. 71 (152) :101-111. Mironov, S.V. and G. Kopij (1996). Three new species of the feather mite family Proctophyllodidae (Acarina: Analgoidea) from some South African pas- serine birds (Aves: Passeriformes). Acarina. 4 (1-2): 27-33.

Mironov, S.V. and G. Kopij (1997). New feather mite species of the subfamily Pterodectinae (Astigmata: Proctophyllodidae) from some passerines (Aves: Passeriformes) of South Africa. Journal of African Zoology. 111 (6): 449-463.

Morsy, T.A.; S.A.M. Mazyad and M.S. Younis (1999). Feather and nest mites of two common resident birds in two ecologically different Egyptian Governorates. Journal of the Egyptian Society of Parasitology. 29 (2): 417-430.

Rueda, L.M. and R.C. Axtell (1997). Arthropods in litter of poultry (broiler chicken and turkey) houses. Journal of Agricultural Entomology. 14 (1): 81-91.

Schuster, R.O. and A.E. Pritchard (1963). Phytoseiid mites of California. Hilgardia, 34 (7): 191-285.

Sinha, R.N. (1979). Role of Acarina in the stored grain ecosystem. In : Rodtiguez, I.G. (Ed.) Recent Advances in Acarology I:263-271. Academic Press Inc., New York.

Sohn, B.O. and Y.T. Noh (1994). Systematic studies of feather mites in Korea. Family Analgidae (Acari, Analgoidea). Korean Journal of Entomology. 24 (1): 81-95.

Young-ShihMin; S.M. Young; HoChyiChen; Chou-LiangYih and LoKangChen. (1999). Feather mites in Taiwan and their parasitical relationship. Proceedings of the 2nd Symposium of Acarology held at Taiwan Agricultural Research Institute, Taiwan, March 24-25, 1999. Chinese Journal of Entomology. Spec. Publ. 12: 71-82.

Zaher, M.A. (1986). Predacious and nonphytophagous mites in Egypt (Nile valley and Delta). Pl. 480 Program 
U.S.A. Project No. EG-ARS-30 Grant No. FG-EG- 139: 518-567.

Zaldivar, L.; C. Fonseca; R. Perez and
N. Cuervo (1988). A new mite species for the fauna of Cuba. Revista Avicultura. 32 (1): 79-88.

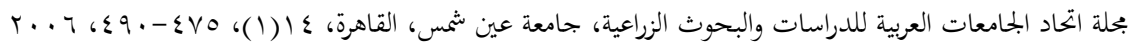

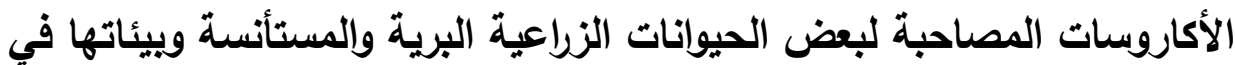
مصر

$[r Y]$

$$
\begin{aligned}
& \text { أحمد عيد عبد المجيد محجوب' - محمود عز الاين ثروت' - سامية عمر كيلاني' - } \\
& \text { طارق شريف حافظ' } \\
& \text { 1. قسم وقاية النبات - كلية الزراعة - جامعة عين شمس - شبرا الخيمة - القاهرة - مصر }
\end{aligned}
$$

r- كان أعلى تعداد للأكاروسات فى فصل

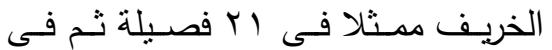
فصل الصيف و الثتاء.

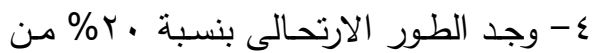

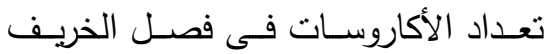

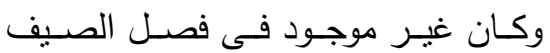
ونادر الوجود في فصل فوجل الشتاء.

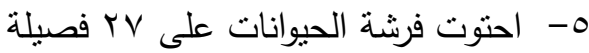

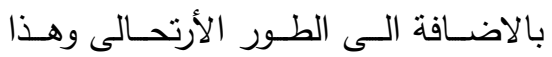
الطور لم يتم العثور علية فى الريش أورئ الغذاء.

צ- كانت نسبة نواجد الأكاروسات والطور

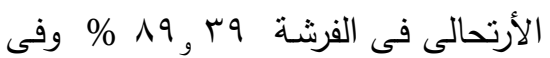

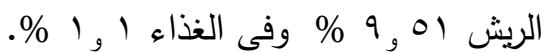

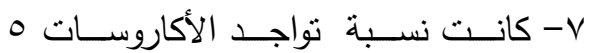

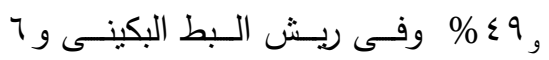
\% \% في ريش الدواجن.
1- تم جمع عينات عشوائية من محافظات الجيزة والقليوبية والمنوفية ، خلال الصيف

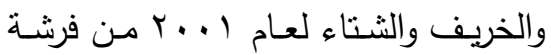
وغذاء وريش الدجاج والبط والبط البكيني

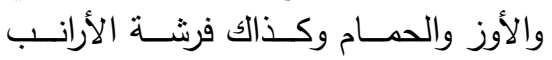

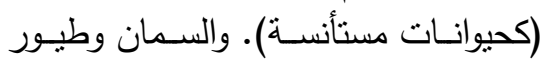

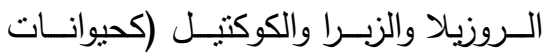

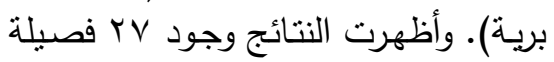

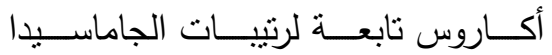
والأكتينيديـــــا والأكاريديـــــا والأوريبانيــــا. بالإضـافة إلي الطور الإرتحـالي لفصيلة أكاريدي.

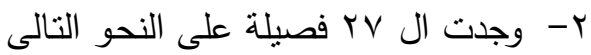

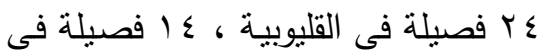

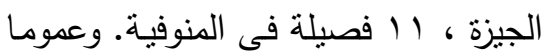
كـان عـد الأكاروسـات ونسـبة سـيادتها فئها مختلف بين الفصائل وكذللك بين المواقع. 
وقد نوقش بالتفصيل بيان دور الحيوانات

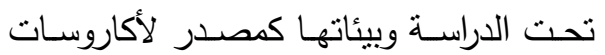

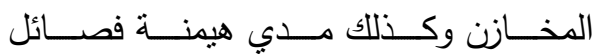
الأكاروسات التي سجل وجودها.

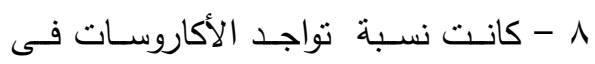

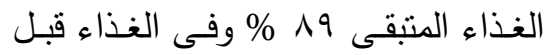

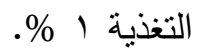
9- كانــت فصـائل الأكاريـدي والكيليتيــدي والجليسيفاجيدي والبيروجليفيدي والأسكيدي والئي والدرمنيسدى الأكثر سيادة وشيوعا.

تحكيم: ا.د عبد السميع حازم يوسف طه

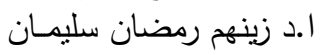

